\title{
The beauty of an icon as absolute cognition
}

For many scholars, the hope of renewing the humanities is a chance to practice their vocation. It is written by attempting to re-engage with research areas of anthropology, phenomenology, hermeneutics and semiotics, disciplines that do not disregard the philosophical and methodological principals that we call "participatory humanities". This humanity annexes the notion of participation strongly embedded in its tradition, especially anthropology and phenomenology. The first is related to the Levi-Bruhl's concept, who understood ritual as activating to be in the sacred reality, the so-called mystical participation; the latter, with Husserlow's origins, equips this notion with the semantics of the concept of experience and directness of insight, which makes the researcher a carrier of the content of the subject. Both these traditions impose cognitive duty to direct existence to a meaningful life and the researcher's responsibility for proclaimed beliefs. Both of them are also in harmony with the ancient tradition, which with humanitas makes a superior value in the cultivation of knowledge.

Hence, the attempt to reactivate the monastic style, and within its framework of critical knowledge (revealed by phenomenology), the practice of presence (eg, the directness of experience, related to not ignoring by the investigator of the so-called "ontological call"), symbolic-spiritual exercises (refering deconstructed ancient Logos, modern humanitas, and the horizon of universal values) ${ }^{1}$. Participatory humanities is, according to preliminary diagnoses, a humanism that

The resurrection of the humanities, at the same time a kind of resurgence of culture, in all its richness, is not a formalist ,resurrection of the word," but the anthropological, hermeneutic and phenomenological turn, demanding to describe the condition of human beings within the framework of the universalist anthropology. Experienced in different times and places. 
cannot be free from showing the relationship of immanence culture and transcendent culture and the relationship of two research areas to the philosophy of ontology and epistemology. Such recognition is aimed at the axiological involvement of the researcher not only in the cognitive but also in the object of the study. W. Stróżewski analyzing the methexis cognitive process, speaks about the relationships between the participating and participated (cognitive subject and cognize object), relations between them, similarity and ontological difference (horizontal and vertical participation), and conditions of participation that makes it possible: there are a dynamic existential relationship that is not a relation of causal causality; the metaphysical difference in modes of existence (the participant is by far weaker than the one in which it participates); to support the existence of the participant, being weaker, from the partisan, to being self-dependent, through this support it can still exist in being. ${ }^{2} \mathrm{~W}$. Stróżewski applies the theory of participation to the art theory, considering, among other things, how a work of art participates in its ontological basis. Referring to various types of art, he points to stained glass - its luminous color - as a result of "participating in light". The light that illuminates it, external to it, the light that gives the stained glass a distinct life from other works: "Light is something transcendent and immanent for it and at the same time, not only a condition of existence, but also a factor constituting its essence" 3 .

These elements of the theory of participation and their application to art enable, in a nutshell, to go beyond the absolute cognition and icon, which are related to the theory of participation and the value of beauty.

Absolute cognition has long been absent in the philosophical salons or modern humanistic trends. One might say that there is a passe. If, however, we decide to go against the trend of fashion trends, we find that they can be revived within the framework of the theory of participation, which recently acquires new areas in the humanities, especially performative one. Taking into consideration the elements of participation theory so far mentioned, it is easy to see that they refresh the metaphysical reflection that lies beyond the pure cognition; they start metar cognition and within it allow the effectiveness of the so- spiritual exercises, the practice of presence, the search for truth and the absolute truth, but also the penetration into the regions of cognition by faith. This kind of cognition is called by J. Leclercq

2 W.Stróżewski,Mimesis i methexis, in: Wokót piękna, Wydawnictwo Universitas, Kraków 2002.

$3 \quad$ Ibidem, p. 78. 
monasticism and brings it closer by sources that document that in the Middle Ages the cult and culture, including science and faith, were not separate, and the search for the Absolute was a passion for the researcher. It is in this style - the monastic style, the opposite of the scholastic style - by the feature ${ }^{4}$, the love of cognition and the desire of God unite with a surprising cognitive harvest; the harvest prepared with the help of ascetic spiritual exercises that charts the way to the Absolute through the participation of the researcher in being involved in the cognitive being; in other words: they responded to the call of transcendent being. As it is quoted by the expert of the subject: "Monastic cognition is defined by the goal of monastic life: seeking God"; what reason can grasp; not using a measure of the mind to believe; opposed "the overcoming of the minds of the learned theologians, for the simplicity of the Church Fathers seeking knowledge on the basis of love and practice of presence (prayer), because one should not give up the faith, the reasonings of reason ${ }^{5}$. The monastic style is in the mere summary: first believe, then understand; fides querens ratio.

Instead of discussing this style of cognition, I refer to St. Anselm, who grows above all the representatives of this cognition ${ }^{6}$. As we know, he is best known for formulating an ontological proof of the existence of God, from which the great philosophers of the past and contemporary (Descartes, Leibniz, Kant, Hegel Schopenhauer, Bertrand Russell, Moor and contemporary Kurt Geodel) were challenged. Here it is: "Let us take into consideration the being that we cannot think about the larger one. Anselm writes that whoever hears this expression, understands it, that is has it in his mind, even if he was not wise. It is easy to see that a being so conceived cannot only be conceived, but

$4 \quad$ See J. Leclercq, Miłość nauki i pragnienie Boga, transl. M. Borkowska, Wydawnictwo Benedyktynów Tyniec, Kraków 1997.

$5 \quad$ J. Leclercq, Miłość nauki..., p. 232, 247, 249, 255.

6 Leclercq, citing the book Historie de la spiritualité by S. Vanni Rovighi, writes: „It is very difficult to properly classify it into a category; This is a genius and therefore cannot fit in any frame. He is a monk and the whole soul follows the patristic tradition that monasticism lives on. At the same time, he is passionate about pure logic; sometimes he tries to approach the faith in the light of reason rather than authority; It is thus synthesized, provisional, imperfect and illusory but bold and proving that he had a sincere confidence in the possibilities of human nature ... But just as someone outside the framework, as an exception, he confirms the normal rule of difference between monks and scholastics. Leclerc, op. cit., p. 329 . 
must exist in reality: for if it is only in thought, then one can think of it as actually existing, and the being is in fact greater than that exists"7.

Commenting on Anzelm's proof, Kolakowski writes:

In other words, a being from which it is impossible to thinkof the bigger one, if it did not exist, it would be such a being from which it is more conceivable to think, that would be something intrinsically contradictory, impossible. To avoid contradictions, we are compelled to recognize that such a being must necessarily exist ${ }^{8}$.

However, the search for the Absolute by St. Anselm does not ends in such a rational inquiry. His desire for God is greater than the philosophical elegance of the proof. St. Anselm, to satisfy this desire, enters into the practice of presence, in contemplation. Here is their record:

Poor man, give up your activities for a moment, take a break, at least from your noisy thoughts, deny the worries that burden you, slow down the tiring distractions. Take a moment to God, rest in Him a little, rest in Him. Enter into your mind's flat, throw away everything except God, and what is going to find Him and shut the door for Him. Say all your heart, say to God: "Yahweh, I love the beauty of your house and the place where your glory dwells» (PS 26:8)"'.

Contemplation of the icon of the Holy Face appears to him as the path to the Absolute.

Any comments we have made on participatory cognition can be referred to the path that accompanies the theology and contemplation of the icon. There is no need and the ability to present, in the broadest sense, this enormous issue that is being made within the various humanistic, theological and artistic options. I will just notice that their condensation contained in M. Quenot's book, The Icon: Window on the Kingdom, corresponds to my findings so far. I am surprised only by Polish translation of the title, which in the original version is: Licône. Fenétre sur l'Absolu ${ }^{10}$. Quenot treats the icon as a place of theology, as

$7 \quad$ L. Kołakowski, Święty Anzelm, in: O co nas pytaja wielcy filozofowie, series I, Wydawnictwo Znak, Kraków 2004, p. 87-88.

L. Kołakowski, Święty Anzelm, in: O co nas pytaja wielcy filozofowie, series I, Wydawnictwo Znak, Kraków 2004, p. 87-88. tuja ewangelie niedzielne roku A. , red. M. Starowieyski, Znak, 1978, p. 1. 
a rational, over-conceptual pursuit of God. He speaks of the icon as "theology in colors"11.

The iconographer by "writing the picture" goes in the direction of God; his purpose is to leave the external, natural determinants of the creation and perfection of its effects, and to reach the inner spiritual realms and perpetuate the beauty that constitutes them. The beauty that carries out iconography is metaphysical, transcendental and is "identified with the essence of the Logos, the deepest meaning that penetrates what exists" 12 .

Let us quote Stozewewski's insightful formulation: "So understood [beauty] is identified with absolute existence. This identification guarantees its transcendentality. All that exists is involved in it ${ }^{\prime 13}$. The beauty, which in the Absolution is identified with Being, is the highest beauty. All others, including the aesthetic, come from it. Hence the Quenot says that "The beauty of icons is not primarily concerned with the finesse of the pattern ... but rather of the harmony manifested in its entirety". To support this statement, he quotes Dostoyevsky's words: "Beauty [God] will save the world" and P. Evdokimov, that "if the [iconographer] desires Beauty, it means that he is immersed in the light, because in his essence there is the rooted desire of Beauty and its image"14. Let us note that the iconographer, like the researcher seeking the truth, is dependent on the Transcendence, the Absolute, God, Christ ${ }^{15}$.

\section{Iconic cognition}

The above findings allow us to say that rational cognition can "rise" to the highest cognition, which is to reach the Absolute, the Beauty of the Supreme. The conditions that enable this cognition override the requirements of rational cognition (eg. intersubjective communicability and controllability of statements) and impose requirements that are related to participant cognition. It launches the cognitive powers (imagination, will) and the goal of cognition - the discovery of the highest truth - the beauty of the Absolute, which governs "cognition", "cognition of love", cognition of the unity of the object participating

\footnotetext{
$11 \quad$ Ibidem, p. 7.

12 M. Stróżewski, Piękno transcendentalne, in: Logos, wartość, miłość, Wydawnictwo Znak, Kraków 2013, p. 83.

13 Ibidem.

$14 \quad$ M. Quenot, op. cit., p. 57.

$15 \quad$ M. Quenot, op. cit., p. 57.
} 
in the Absolute-Beauty-God. In this sense, the cognitive style is found in the iconic extension.

By referring directly to art, it can be said that through painting the icons according to certain rules that honor painting character ${ }^{16}$, semiotic principles, transcends them by "knowing love" enters the areas of metaphysical reality, invisible. In this sense, iconic cognition is over ratio and is cognition qualified as a cognitive knowledge; cognition, which strives to unite the cognizable and cognized subject, is guided by a trust, uncoordinated relationship, ratio and fides.

In this iconic cognition, beauty becomes a substitute for God; it is an ontological beauty. In short, it is beautiful in the sense of Saint. Augustine, for whom he reveals the truth of God and beauty in the sense of Saint Thomas Aquinas, which merges essence and existence. Transcendental beauty, individually experienced by St. Augustine is like an ontological call: "You called, you called, you threw my deafness. You shone, you glowed like lightning, you lighted my blindness. You scented the odor, I breathed it out - and here I thirst for you. I tasted - and here I am hungry, and I am starving. You touched me - and I longed for your peace"17.

The beauty of St. Thomas Aquinas is an ontological par excellence: pulchra enim dicuntur, quae visa placent (Theological sum I, 5, 4). ${ }^{18}$

The theory of transcendentality, which equates beauty with being, in iconic and absolute cognition at the same time equates it with God: the Supreme Being is at the same time the highest and the most authentic Beauty.

According to W. Stróżewski, the same being is realized in all kinds of beauty, which by the specific entities is only limited by obscurity ${ }^{19}$. Beauty is the perfection of fulfillment and the necessity associated with it; the attributes of the essence of beauty: supremacy and necessity, and the changing entities are: harmonious balance and its agitation, proportion and perfection, brightness and darkness, asceticism and splendor ${ }^{20}$.

Therefore, the "highest of beauty" is placing it in the Platonic triad. In it, it acquires ontological, epistemological and axiological attributes. Beauty is the truth and the good. It is the highest value and

16 W. Panas, Sztuka jako ikonostas, p. 137, Biblioteka Multimedialna; pierwodruk „Znak” 1982, no 337, p. 1522-1542.

17 Cf. Jak zaswędzi, to Duch Święty. Wiara i zmysty, wywiad z Pawłem Krupą OP, „W drodze”, 2/2016, p. 10-11.

18 Cf. P. Jaroszyński, Piękno, PEF, Polskie Towarzystwo Tomasza z Akwinu, p. 3.

19 W. Stróżewski, Wokót piękna, op. cit. p. 424, 425.

20 Ibidem, p. 430. 
the imperative; sense of life and art. Hence St. Augustine said "The beautiful works that the soul reproduces with the hands of artists have a source in that beauty, higher than the souls to which my soul misses day and night" 21 . If God is the source of beauty, the icon is the way to him, the "window to the Absolute."

\section{The icon as a symbol}

Opening up to metaphysics, which is the metaphysics of beauty and its transcendentality, guarantees access to the truth as a manifestatio - the truth as an unveiling as a revelation ${ }^{22}$. This kind of the truth Theology of beauty reveals the duality of beauty - its sensuality and transcendence, the beauty itself is given the status of the symbol: "Beauty is in essence and necessarily a symbol ..."23.

If we take into account the permanent determinant of beauty - the necessity, then - according to W. Stróżewski ${ }^{24}$ - transcendence - that is, unity and duality, sensuality and spirituality, our revelation is similar to the symbol in which the meaning symbolizes reality in which it participates ${ }^{25}$.

According to the cited author, the call of beauty unites man's earthly desires with the desires of the Absolute: "Beauty is the key to the mystery and the call of transcendence. It encourages man to experience the taste of life and to dream of the future. That is why the beauty of created things cannot bring him satisfaction and awakens this latent longing for God, which Saint Augustine, beautifully lavished, was able to express in unmatched words: "Late have I loved you, beauty so old and so new: late have I loved you" 26 .

The content symbolizing the icons, reaching the symbolic reality, reaches the Absolute. Cognition by the icon as participative cognition is a unifying cognition, in which cognition of the truth manifestatio is cognition of the essence and existence, that is, of God. If we accept together with Plotinus or Pseudo-Dionysia Areopagite, that art as

\footnotetext{
$21 \quad$ St. Augustine, Confessions, X, 34.

About the truth as manifestatio see W. Stróżewski, Tak - tak, nie - nie (Kilka uwag o prawdzie), in: Logos, wartość, mitość, op. cit.

E. Cassirer, Problem symbolu ijego miejsce w systemie filozofii, in: Symbol ijęzyk, transl. B. Andrzejewski, Poznań 1995, p. 45-46.

W.Stróżewski, O pięknie, in: Wokótpiękna, Universitas, Kraków 2002, p. 164-168.

W. Stróżewski, Symbol i rzeczywistość, in: Istnienie i sens, Kraków 1994.

26

W. Stróżewski, O pięknie, in: Wokót Piękna, p. 168.
} 
a symbol is directly related to reality, which is beauty ${ }^{27}$, thus confirming that it can express what is inexpressible, absolutely transcendent, God and Beauty ${ }^{28}$.

Moreover, according to Evdokimov, the icon as the call of the Transcendence illustrates the "invisible reflection of divine beauty" 2 . To confirm his conviction, we can refer to a specific example that illustrates the truth of the icon as a manifestatio - the example of "beautiful Lady" - Bernadette of Lourdes, who not only indicated her similarity to the icon but also brought it to beauty and glamor (Figure 3 - "Bernadette's icons") ${ }^{30}$.

Hence, if we assume that the beauty of the icon is "the sine qua non condition of its essence and its mysterious existence"31, then we can say that the art of icons is participation in objective existence; it is a manifestation of objectively existing values: truth, good and beauty, and not only in subjectively understood aesthetic values; that icon truth as manifestatio transmitted by imitation of truth about sacred transcendent reality - the "thing" immitated; that is the revelation of the Absolute.

\section{The icon as a way to the Absolute}

The ontology and epistemology of beauty in the icon and in the associated iconic cognition accepts universal and individual forms simultaneously. As their constipation, one can receive the cognitive experience of St. Anselm whose logical and semiotic cognition simultaneously "elevates" to the contemplation of the icon of the Holy Face (illustrations 1,2) of the icon of the Holy Face).

This "icon of icons" 32 , treated as a canonical one, is painted according to the rules that give it its unequivocal and powerful semiosis, and at

27 Pseudo-Dionizy Areopagita, Pisma teologiczne, transl. M. Dzielska, Kraków 1997, p. 83-84.

W. Stróżewski, O pięknie, op. cit. p. 171.

P. Evdokimov, Sztuka ikony. Teologia piękna, transl. M. Żurowska, Warszawa 1999 , p. 20.

30 I write more about this topic in:Źródto, eadem, Moi święci, Flos Carmeli, Poznań 2015.

W. Stróżewski, O pięknie, op. cit., p. 168-169,

I write more about this topic in: Edyta Stein w świetle ikony, in: Fenomen Edyty Stein. Das Phänomen Edith Stein, „Zeszyty Naukowe CBES”, Wydawnictwo Naukowe UAM, Poznań 2014. 
the same time metaphysical and sanctifying transition from the sphere of profane to the reality of the existent reality - the sacred reality.

The icon of the Holy Face fits into the workshop conventions of writing the icon and opens it up for participant cognition. St. Anselm is experiencing such cognition, although he does not write icons. It is the contemplation of this icon that enables him to move directly from the sphere of philosophical thought, fostered by rational reasoning to the field of unity with God. Let us note that the rules of rational thought, visible in his proof for the existence of God, open it to His Almighty, Infinity, Absolute. I would like to say that the "beauty of reason" forming the canon of philosophical command in the case of St. Anselm prepares it by its volitional openness to the elevation of the metaratial contemplation of the "beauty of the icon", which becomes the "window to the Absolute," the perfect God. The canonization of the icon of the Holy Face harmoniously co-creates the cognition of the Supreme God.

Let's change in the illustration of the problem of iconic cognition. Let>s take a look at the example of the icon of Merciful Jesus, who does not seem to fulfill the iconic conventions and at the same time attests to the cognition of another image of God. God who is not the Absolute but the Merciful God. Let>s refer to the participation experience of St. Faustina, which is directly related to experiencing the Revelation truth and its iconic transmission. Many holy records suggest that we are dealing with the "dictation" of the rules according to which the icon of Jesus manifesting himself is to be painted. E.g:

Paint an image according to the pattern you see, with the signature: Jesus, I trust in You. I desire that this image be venerated, first in your chapel, and [then] throughout the whole world ${ }^{33}$.

During prayer I heard these words within me: "The two rays denote Blood and Water. The pale ray stands for the Water which makes souls rightous. The red ray stands for the Blood which is the life of souls ... These two rays went out from the entrails of My mercy at that time, when My dying heartwas opened by a spear on the Cross." ${ }^{34}$.

It would seem that the iconic "instructions" issued by the manifesting God create the icon par excellence; the icon whose rules of "writing" are the most perfect. And yet you do not need a great erudition to say that it is a non-canonic icon; the principle of the perfection of iconic

\footnotetext{
33 s. M. Faustina Kowalska, Dzienniczek. Miłosierdzie w duszy mojej [Diary], Wydawnictwo Księży Marianów, Warszawa 1993, no 47, p. 36. 
Theology of beauty

creation is ignored in it. So, what is the relationship between "writing" and cognition that participates and unites with God?

For the answer we can accept the following St. Faustina's notes:

"On one occasion, Jesus gave me to know how pleasing to Him is the soul that faithfully keeps the rule. A soul will receive a greater reward for observing the rule than for penances and great mortifications. The latter will be rewarded also if they are undertaken over and above the rule, but they will not surpass the rule." 35

From this and other records we can say that Jesus' "rules" refer to the recitation of the Chaplet of the Divine Mercy ${ }^{36}$; it does not include the canonical perfection of the icon, but the prayerful and fruitful participation in the mercy of God. Hence, the signature "Jesus trusts in You", dictated by Him through Faustina, is clearly integrated with the image. Jesus says to st. Faustina: "I am offering people a vessel with which they are to keep coming for graces to the fountain of mercy. That vessel is this image with the signature: Jesus, I trust in You" ${ }^{37}$.

It is naive to ask whether St. Faustina is iconically aware of other God than St. Anselm? Does the process of this cognition unite the same God? It is impossible to resolve these issues within an occasional theme; also a fundamental theme for beliefs about connectivity ratio and fides. At this point it is enough to quote St. Faustina's words addressed to her by Jesus: "Proclaim that mercy is the greatest attribute of God. All the works of My hands are crowned with mercy". 38

The words of Jesus addressed to St. Faustina: "My view of this image is as a look from the cross," they integrate not only the picture with the subtitle "Jesus, I trust in You," but earthly with divine reality. This integration does not have a canonical icon; this provides the icon "written" according to "instructions" manifesting to Faustina by Christ (illustrations $3,4,5,8)$. The derivation, requiring a separate explanation, is the image of E. Kazimirowski (fig. 9) and the Icon of the Carmelite Divine Monastery in Szczecin (fig. 6.7) - confirming the separation of the subtitle and the image as the rule in the canonical icon ${ }^{39}$.

\footnotetext{
$35 \quad$ Ibidem, no 189 , p. 91.

36 Ibidem, no 476, p. 165-166.

37 Ibidem, no 327, p. 124.

$38 \quad$ Ibidem, no 301, p. 118.

39 Initially, the painting by E. Kazimirowski was not signed; the attempt to place, after the Second World War, the inscription „Jesus, I trusts in You”, made in red letters, failed; The inscription that „broke" the composition of the image was abolished; It was later added without integrating with the image. The Szczecin icons of Merciful Christ do not strictly follow the convention of the classic
} 


\section{Spiritual beauty}

Faustina's Diary abounds in the formulation of spiritual beauty. The statement "how beautiful is the inner world" 40 will confirm the recognition of spiritual beauty as the beauty of participatory cognition in which the cognizant subject is the witness ${ }^{41}$ of the truth in the manifestatio sense.

Christ is the link in cognition of the absolute:

My mercy has passed into souls through the divine-human Heart of Jesus as a ray from the sun passes through crystal. I felt in my heart and understood that every approach to God is brought about by Jesus, in Him and through $\mathrm{Him}^{42}$.

Jesus to St. Faustina: "I am making you the administrator of My mercy. Tell the confessor that the Image is to be on view in the church and not within the enclosure in that convent. By means of this Image I shall be granting many graces to sous; so, let every soul have access to it" $" 43$.

Jesus said to Faustina:

I will tell you most when you converse with Me in the depths of your heart. Here, no one can disturb My actions. Here, I rest as in a garden enclosed ${ }^{44}$.

"Crystal dwelling" of "inexplicable brightness", inhabited by the "Unity of Trinity, which is incomprehensible, infinite" and filled with "depths of mercy" of God".

These quotes refer to "cognition of the heart", to cognition of the participant uniting the Merciful Jesus.

In the iconic image of the Merciful Christ, God does not appear to be the greatest, but embraces the least: "It is the property of God that it

icon; They are executed with and without an inscription. Confusion around the inscription confirms my remarks on the canonicality of the classic icon and the causes of the non-canonical icon of the Merciful Christ.

s. M. Faustina Kowalska, Dzienniczek. Miłosierdzie w duszy mojej [Diary], op. cit., no 448, p.159.

1 Ibid, no 417, p. 150: ,Then I heard these words: «You are my witness of my mercy, forever standing before my throne as a living witness of my mercy»."

Ibidem, no 528, p. 180.

Ibidem, no 570, p. 192.

Ibidem, no 580, p. 195.

Ibidem, no 420, p. 151. 
Theology of beauty

does not include the greatest, and the least possible" ${ }^{46}$. Contemplative cognition of St. Anselm referring to the icon of the Holy Face is permeated by the attribute of God's greatest size. St. Faustina's icon-image refers to the attributes of the greatest minority; attributes that break the rules of conventional canonical perfection. The truth revealed in God's Mercy in these rules cannot fit. Its saving power seeks integral expression: words and representations; the words that make up and the image that radiates them. This integrity creates new conditions for the appearance of the beauty of mercy. Merciful Christ comes to those who fulfill them; those who pray "chaplet" to the "heart of Jesus". It is possible to risk the conviction that the non-canonicity of the icon of the Merciful Christ extends the cognition of God to his infinite mercy, which becomes his greatest attribute. Iconic cognition that is known to his image "without rules" opens to individual participation in the various faces of His Presence ${ }^{47}$. This participation achieves its purpose under the condition that it is transformed into an entity that "cognise by the heart", that is, with love and is afflicted by Love, that is by God. These conditions guarantee absolute cognition. The salutary icon of the Merciful Christ can mediate in it, as an icon integrating the earthly, natural, with the spiritual and the supernatural reality. The icon of noncanon - icon without borders - breaking conventions, creates new conditions for Beauty, which is the Merciful Christ breaking the stereotype of $\operatorname{God}^{48}$. The icon of the Holy Face, on the other hand, mediates in the contemplation of the image, which draws near to God the Creator. Its canonicality places the limits of human imagination and will, protecting the sacred from the possibility of profanation resulting from them. Probably, however, it does not impose access to God. Absolute cognition, in the case of both icons, forces the boundaries between fides and ratio. It merges and unites, metaphorically speaking, Heaven and Earth ${ }^{49}$. Cf. J. Ratzinger, Introduction to Christianity, p. 147.

47 See J.-P. de Caussade, Powierzenie się Bożej Opatrzności, Wydawnictwo WAM, Kraków 2003.

Cf. D. Piórkowski SJ, Książeczka o miłosierdziu, WAM, Kraków 2015, p. 93.

Our reflections correspond to W. Panas' observations from his earlier article. On the basis of them it can be said that the pre-seminary state enables the highest cognition - the absolute cognition (contemplation of the Holy Face), contemplative, eg „paradise of the prajna”; Watching the Creator face to face, not through the veil of mirror characters. In his semiotic stand, St. Anzelm's proof for the existence of the God would be in „paradise communication”; outside the linguistic sign; beyond rational philosophical cognition, where essence coincides with phenomena; See also Mauricio Beuchot, Kwadrat semiotyczny
} 


\section{Illustrations:}

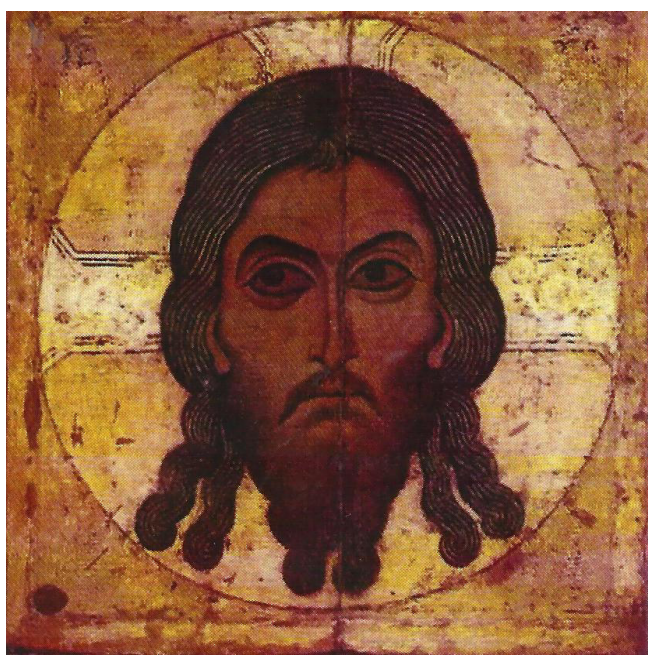

Fig. 1. Icon of the Holy Face I.

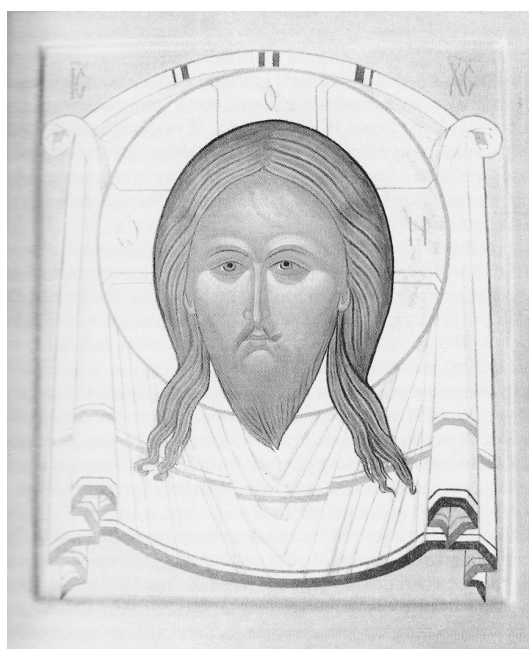

Fig. 2. Icon of the Holy Face II.
Theology of beauty

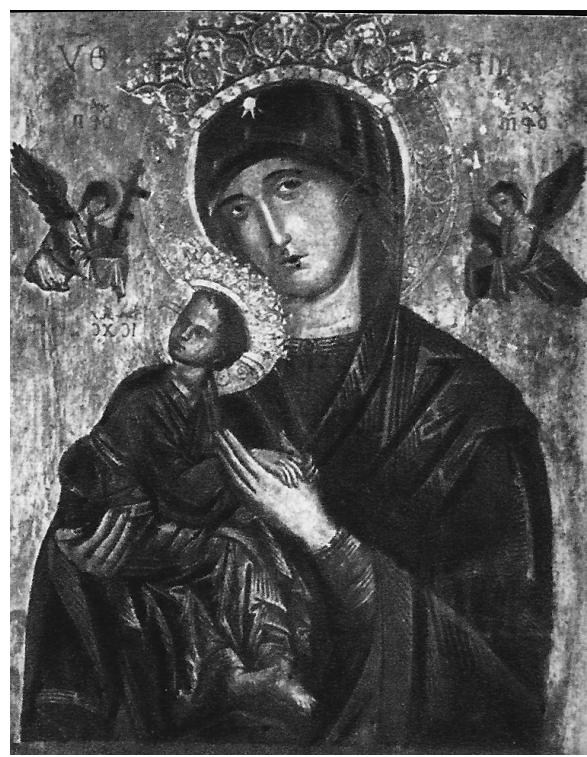

Fig. 3. Icon of the Blessed Virgin Mary seen by Bernadette of Lourdes.

świętego Anzelma a kwadrat semiotyczny Greimasa, in: Idac za Greimasem, ed. A. Grzegorczyk, M. Loba, Wydawnictwo Fundacji Humaniora, Poznań 1999. 


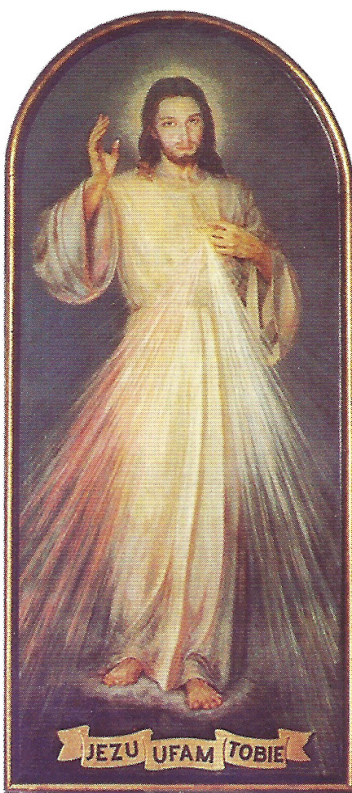

Fig. 4. Icon of Merciful Christ by A. Hyła

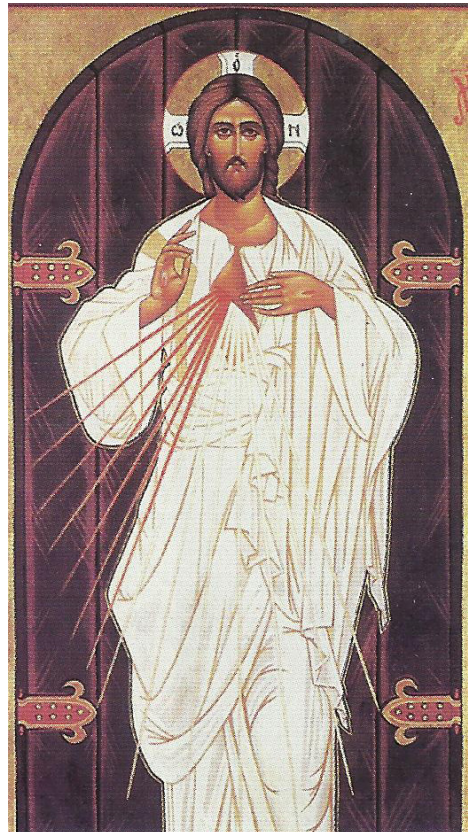

Fig. 6. Icon of Merciful Christ, Carmelites in Szczecin

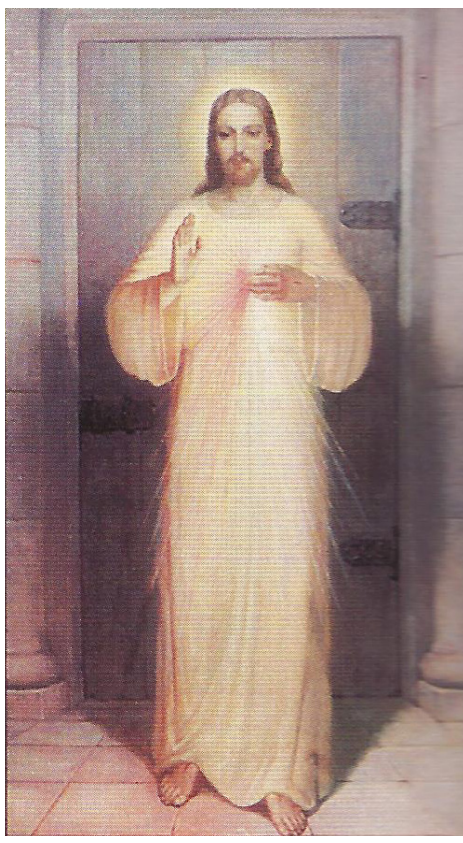

Fig. 5. Icon of Merciful Christ by L. Sledzinski

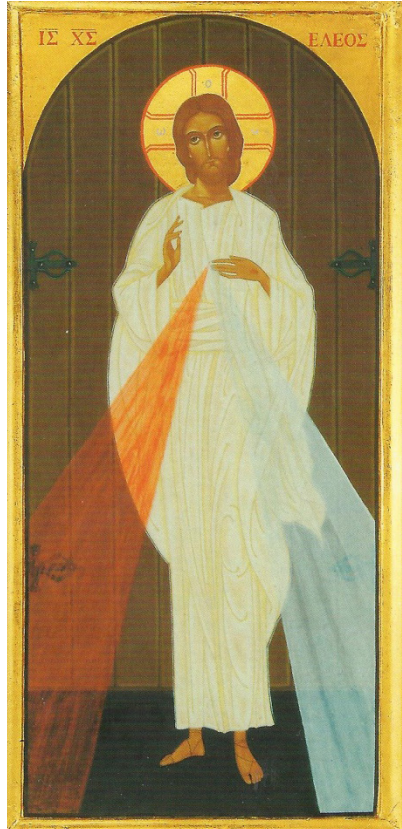

Fig. 7. Icon of Merciful Christ, Carmelites in Szczecin 


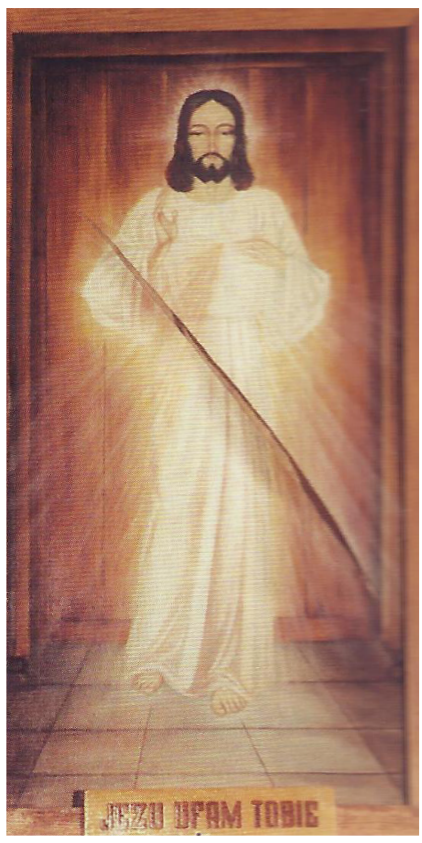

Fig. 4. Icon of Merciful, Myślibórz

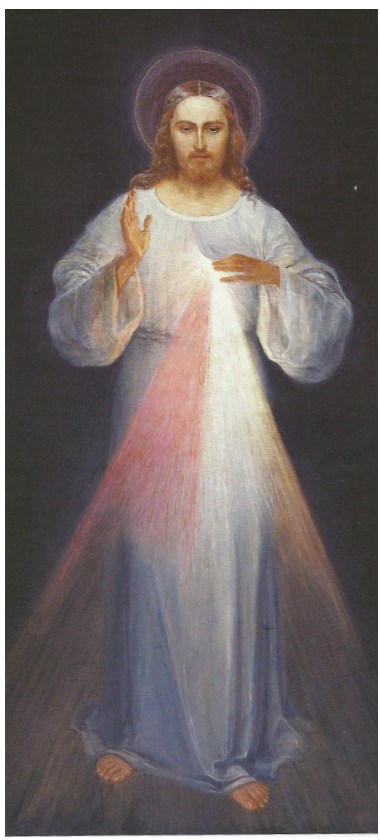

Fig. 4. Icon of Merciful Christ by

E. Kazimirowski

\section{PIĘKNO IKONY JAKO POZNANIE ABSOLUTNE}

Niekwestionowana więź ikony i prawdy aktualizuje problem poznania absolutnego. Poznanie to przebiega procesualnie w oparciu o doświadczenie estetyczne i religijne uruchamiając kategorię obecności jako konieczną do poszerzania możliwości poznania przestrzeni transcendentnych i sakralnych zarazem. Więzi ikony i słowa, ikony i obrazu, ikony i dźwięku, ikony i prawdy wyznaczają metafizyczne i meta racjonalne tory poznania, które stanowić mogą argument kalokagatyczny na istnienie Boga i kształtować poznanie najwyższe - absolutne. Poznanie ikoniczne jako poznanie absolutne wpisuje się tym samym w filozofię mądrościową i może spełniać funkcję fundamentalną dla kształtowania humanistyki obecności.

Słowa kluczowe: Humanistyka mądrościowa, poznanie absolutne, poznanie metaracjonalne, poznanie ikoniczne, obecność, doświadczenie religijne i estetyczne, ikona-słowo, ikona-obraz, ikona dźwięk, ikona-prawda, argument kalokagatyczny. 


\section{Bibliography:}

1. Beuchot M., Kwadrat semiotyczny świętego Anzelma a kwadrat semiotyczny Greimasa, in: Idac za Greimasem, ed. A. Grzegorczyk, M. Loba, Wydawnictwo Fundacji Humaniora, Poznań 1999.

2. Cassirer E., Problem symbolu i jego miejsce $w$ systemie filozofii, in: Symbol i język, transl. B. Andrzejewski, Poznań 1995.

3. Caussade J.-P. de, Powierzenie się Bożej Opatrzności, Wydawnictwo WAM, Kraków 2003.

4. Evdokimov P., Sztuka ikony. Teologia piękna, transl. M. Żurowska, Warszawa 1999.

5. Grzegrczyk A., Edyta Stein w świetle ikony, in: Fenomen Edyty Stein. Das Phänomen Edith Stein, „Zeszyty Naukowe CBES”, Wydawnictwo Naukowe UAM, Poznań 2014.

6. Grzegrczyk A., Moi święci, Flos Carmeli, Poznań 2015.

7. Jak zaswędzi, to Duch Święty. Wiara $i$ zmysty, wywiad z Pawłem Krupą OP, „W drodze”, 2/2016.

8. Jaroszyński P., Piękno, PEF, Polskie Towarzystwo Tomasza z Akwinu.

9. Karmię Was tym, czym sam żyję. Ojcowie Kościoła komentuja ewangelie niedzielne roku A. , ed. M. Starowieyski, Znak, 1978.

10. Kołakowski L., Święty Anzelm, in: O co nas pytaja wielcy filozofowie, series I, Wydawnictwo Znak, Kraków 2004.

11. Kowalska F., Dzienniczek. Miłosierdzie w duszy mojej [Diary], Wydawnictwo Księży Marianów, Warszawa 1993.

12. Leclercq J., Miłość nauki i pragnienie Boga, transl. M. Borkowska, Wydawnictwo Benedyktynów Tyniec, Kraków 1997.

13. Ouenot M., Ikona. Okno ku wieczności, transl. H. Paprocki, Białystok 1997.

14. Panas W., Sztuka jako ikonostas, Biblioteka Multimedialna; pierwodruk „Znak” 1982, no 337.

15. Piórkowski D., Książeczka o miłosierdziu, WAM, Kraków 2015.

16. Pseudo-Dionizy Areopagita, Pisma teologiczne, transl. M. Dzielska, Kraków 1997.

17. Ratzinger J., Introduction to Christianity.

18. St. Augustine, Confessions, X, 34 .

19. Stróżewski W., Mimesis i methexis, in: Wokót piękna, Wydawnictwo Universitas, Kraków 2002.

20. Stróżewski W., O pięknie, in: Wokót piękna, Universitas, Kraków 2002.

21. Stróżewski W., Piękno transcendentalne, in: Logos, wartość, mitość, Wydawnictwo Znak, Kraków 2013.

22. Stróżewski W., Symbol i rzeczywistość, in: Istnienie i sens, Kraków 1994.

23. Stróżewski W., Tak - tak, nie - nie (Kilka uwag o prawdzie), in: Logos, wartość, miłość, Wydawnictwo Znak, Kraków 2013. 